\title{
Global Motor, Oral and Deglutition Characteristics in Children with Cerebral Palsy
}

\section{Características Motoras Globais, Orais e de Deglutição em Crianças com Paralisia Cerebral}

\author{
Moisés Andrade Santos de Queiroz*a; Priscilla Mayara Estrela Barbosa ${ }^{\mathrm{b}}$; Andréa Cintia Laurindo Porto ${ }^{\mathrm{a}}$; \\ Izabella Santos Nogueira de Andrade \\ aFortaleza General Hospital. CE, Brazil.

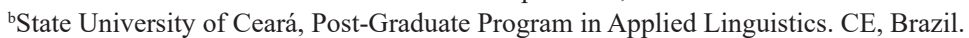 \\ ${ }^{\mathrm{c} U n i v e r s i t y ~ o f ~ F o r t a l e z a, ~ C e n t e r ~ o f ~ H e a l t h ~ S c i e n c e s, ~ S p e e c h ~ T h e r a p y ~ C o u r s e . ~ C E, ~ B r a z i l ~}$ \\ *E-mail: moisesandrade@live.com \\ Recebido em: 31/08/2020 \\ Aprovado em: 01/12/2020
}

\begin{abstract}
Cerebral palsy (CP) is a disorder in postural and movement tone resulting from involvement in the motor centers of the immature brain. Thus, this work sought to expose the global motor, oral, and deglutition characteristics in children with CP. To this end, it performed a cross-sectional study of 100 children with CP. The data collection consisted in the detection of the main global motor and oral alterations, their repercussions on the deglutition process, and the main manifestations of dysphagia according to different consistencies of food and types of cerebral palsy. All children exhibited global motor and oral alterations. There were significant differences between age and global motor alterations. Alterations in the tongue mobility were more present in spastics $(\mathrm{p}=<0.031)$. The main manifestations of dysphagia, in decreasing order of occurrence were: premature liquids spillage (70\%), cough (60\%), decreased bolus formation in solids $(57,9 \%)$, presence of food residues in the oral cavity $(47,4 \%)$, increased pasty oral transit $(47,1 \%)$ and presence of wet voice after the liquids swallowing $(30 \%)$. Therefore, the influence of pelvic instability and compensatory patterns was observed in the presence of clinical signs of tracheal aspiration. Regardless the type of CP, the global and oral motor alterations lead to deglutition disorders.
\end{abstract}

Keywords: Cerebral Palsy. Child. Deglutition Disorders. Posture

\section{Resumo}

A paralisia cerebral (PC) é uma desordem no tônus postural e de movimento decorrentes de um acometimento nos centros motores do cérebro imaturo. Com isso buscou apresentar as características motoras globais, orais e de deglutição em crianças com PC. Assim, realizou um estudo transversal com amostra de 100 crianças com PC. A coleta de dados consistiu na detecção das principais alterações motoras globais e orais, a repercussão na dinâmica da deglutição e as principais manifestações disfágicas em diferentes consistências alimentares. Todas as crianças apresentaram comprometimentos motores globais e orais. Houve diferença significante entre a idade e as alterações globais. Alteração na mobilidade da língua esteve mais presente em espásticos $(\mathrm{p}=<0,031)$. As principais manifestações disfágicas, em ordem decrescente de ocorrência, foram: escape anterior de líquidos $(70 \%)$, tosse $(60 \%)$, diminuição da formação do bolo alimentar no sólido $(57,9 \%)$, presença de resíduos alimentares na cavidade oral após a deglutição de sólidos (47,4\%), aumento do trânsito oral de pastoso $(47,1 \%)$ e presença da voz molhada após a deglutição de líquidos (30\%). Então, observou-se a influência das alterações tônicas e posturais na presença de sinais clínicos de aspiração traqueal. Alterações tônicas e posturais com comprometimentos motores orais acarretam transtornos da deglutição em crianças com PC.

Palavras-chave: Paralisia Cerebral. Criança. Transtornos da Deglutição. Postura

\section{Introduction}

Cerebral palsy (CP) can be defined as disorder of postural tonus and movement resulting from an injury or dysfunction in the motor centers of the immature brain, which occurred from the intrauterine life to the first two years of life ${ }^{1}$. This characterizes a specific group of non-progressive chronic encephalopathy, of a mutable character, which can be classified according to the lesion site and alterations of muscle tonus in spastic, atetoid, ataxic or mixed. Topographical distribution in turn can be hemiparetic, diparetic or tetraparetic, according to the degree of motor damage presented ${ }^{2}$.

Regardless its clinical classification, the neuropsychomotor development of the child with PC occurs in an unorganized manner, with the persistence of primary motor patterns, the appearance of abnormal patterns and pathological reflexes ${ }^{4,5}$. These alterations inhibit the reactions of rectification, balance and protection, resulting in delay or prevention of head, trunk and pelvis control, causing disorders in proximal tonus, oral and motor performance and, consequently, deglutition dynamics $^{6-11}$.

Impairment in the functioning of any phase and/or among the phases of deglutition (oral preparatory, oral pharyngeal and esophageal preparation), causes deglutition disorders, which, in childhood, are often associated with PC cases, characterizing the clinical sign called neurogenic oropharyngeal dysphagia ${ }^{7-9}$.

The clinical speech-language intervention in oropharyngeal 
dysphagia recognizes that the adequate biomechanical alignment, together with the global motor stability, are determining factors for the modification of pathological patterns and better functionality of oral structures, reflecting positively on deglutition, which is justified by the decrease in food tracheal aspiration, dysphagic manifestation that carries risks of malnutrition, dehydration and aspiration pneumonia?

In view of the above, the present study aims to present the global motor, oral and deglutition characteristics in children with cerebral palsy.

\section{Material and Methods}

Prior to the execution of this study, the project was evaluated and approved by the Research Ethics Committee of University of Fortaleza (UNIFESP) under number 105/19. The children's guardian participating in the study signed a Free and Informed Consent term, as prescribed in Resolution $\mathrm{n}^{\circ} 466 / 12$, of the National Health Council (CNS).

A quantitative, cross-sectional, individualized and observational study was carried out in children diagnosed with CP in the Occupational Therapy sector of the Integrated Medical Care Center (NAMI), from February to October 2019, in the city of Fortaleza, capital of the State of Ceará, Brazil.

Children diagnosed with PC were included, regardless of pre, peri and postnatal factors and type of PC. The exclusion criteria were those children who presented structural anomalies of oropharynx and/or who were unable to eat orally.

The sample consisted of 100 children with $\mathrm{CP}$, with an average age of one year and six months, ranging from one to five years of chronological age, 54 of whom were male and 46 of whom were female.

Data collection was performed through the application of the Speech-language Clinic Evaluation Protocol, used in the Occupational Therapy sector of NAMI. In this protocol, there are relevant data on the children's clinical history, including information on complications, treatments, dietary and respiratory conditions.

During the evaluative procedure, the posture, tonus and global mobility were examined, investigating: independent head control, head and trunk alignment, besides the presence of pathological reflex activity such as asymmetrical cervical tonic reflex - MCA, labyrinth tonic reflex - RTL, Symmetrical Cervical Tonic Reflex - RTCS. The existence of compensatory patterns used as a defense means for motor acts, such as head hyperextension, elevation and/or shoulder retraction, was also observed.

The analysis of oral structures of lips, cheeks and tongue were evaluated in terms of posture, tonus, mobility and sensitivity.

The presence of pathological oral reflexes was investigated through the observation of: vomiting, tonic bite, exaggerated jaw opening, transverse tongue, tongue protrusion, demand and sucking.

Finally, the presence of dysphagic manifestations was observed by evaluating the food deglutition in the liquid, liquid thickened, pasty and solid consistency at room temperature. During the food supply, it started with pasty, since it is the consistency that offers the lowest risk of aspiration. The children used the utensils and were positioned in usual feeding situations, following the previous phonoaudiological guidelines on postural control, in which $40 \mathrm{ml}$ of liquid (water) was consumed in the glass, $40 \mathrm{ml}$ of thickened liquid (Nestlé ${ }^{\circledR}$ yogurt) in the spoon, $40 \mathrm{ml}$ of pasty (Nestlé ${ }^{\circledR}$ yogurt plus two spoons of $10 \mathrm{ml}$ of Thick \& easy ${ }^{\circledR}$ instant food thickener) in the spoon and solid (two Maizena ${ }^{\circledR}$ biscuits), following the clinical evaluation protocol of NAMI deglutition.

Cervical auscultation was also performed in order to identify the presence of pharyngeal alterations such as the presence of laryngeal penetration, tracheal aspiration and food residues. It should be emphasized that initially these children were submitted to clinical evaluation and, depending on the need, the presence of clinical signs suggestive of aspiration, these were referred to Deglutition Nasoendoscopy.

The following variables were considered for clinical speech-language evaluation: a) global motor alterations in: global motor tonus, head control, head and trunk alignment, pathological reflex activity and compensatory pattern presence; b) oral motor alterations in: posture and lip tonus; posture, tonus and tongue mobility and presence of pathological oral reflexes; and c) dysphagic manifestations: anterior escape of saliva and food, increase of oral transit, decrease of the food bolus formation, food residues, cough and wet voice through cervical auscultation.

After the analysis of the variables described, the main global motor, oral and dysphagic manifestations found in the various food consistences in the different types of CP were observed.

For the statistical analysis among the variables of each group, it was chosen to use the ANOVA, Fisher's Exact and Two-Proportion Equality tests, performed using the SPSS v16 software, considering the significance level $\mathrm{p}=<0.05$.

\section{Results and Discussion}

The main global motor changes, in decreasing order of occurrence, were: global muscle tone alteration (100\% 100/100); postural changes and presence of pathological reflex activity (86\%); head control alteration (64\%); lack of head and trunk alignment (60\%); and presence of compensatory standards (38\%) (Table 1). 
Table 1 - Global motor aspect for each type of cerebral palsy.

\begin{tabular}{|c|c|c|c|c|c|c|}
\hline \multirow{2}{*}{\multicolumn{2}{|c|}{ Global Motor Aspect }} & \multicolumn{2}{|c|}{$\begin{array}{c}\text { Athetoid } \\
(\mathrm{N}=36)\end{array}$} & \multicolumn{2}{|c|}{$\begin{array}{l}\text { Spastic } \\
(\mathrm{N}=64)\end{array}$} & \multirow{3}{*}{$\begin{array}{l}\text { p-value } \\
<0.001 *\end{array}$} \\
\hline & & \multirow{2}{*}{$\begin{array}{l}\mathbf{N} \\
26\end{array}$} & \multirow{2}{*}{$\frac{\%}{72.2 \%}$} & \multirow{2}{*}{$\begin{array}{c}\mathbf{N} \\
0\end{array}$} & \multirow{2}{*}{$\begin{array}{c}\% \\
0.0 \%\end{array}$} & \\
\hline & Floating & & & & & \\
\hline Global Motor & Hypertonic & 0 & $0.0 \%$ & 44 & $68.8 \%$ & $<0.001^{*}$ \\
\hline & Hypotonic & 10 & $27.8 \%$ & 20 & $31.3 \%$ & 0.797 \\
\hline \multirow{2}{*}{ Head Control } & Changed & 22 & $61.1 \%$ & 42 & $65.6 \%$ & \multirow{2}{*}{0.750} \\
\hline & Appropriate & 14 & $38.9 \%$ & 22 & $34.4 \%$ & \\
\hline \multirow{2}{*}{ Trunk stability } & Changed & 18 & $50.0 \%$ & 42 & $65.6 \%$ & \multirow{2}{*}{0.279} \\
\hline & Appropriate & 18 & $50.0 \%$ & 22 & $34.4 \%$ & \\
\hline \multirow{2}{*}{ Pelvic stability } & Changed & 30 & $83.3 \%$ & 56 & $87.5 \%$ & \multirow{2}{*}{0.684} \\
\hline & Appropriate & 6 & $16.7 \%$ & 8 & $12.5 \%$ & \\
\hline \multirow{2}{*}{$\begin{array}{c}\text { Compensatory } \\
\text { standards }\end{array}$} & Absent & 18 & $50.0 \%$ & 44 & $68.7 \%$ & \multirow{2}{*}{0.190} \\
\hline & Present & 18 & $50.0 \%$ & 20 & $31.3 \%$ & \\
\hline
\end{tabular}

* Statistically significant values $(\mathrm{p} \leq 0,05)$ - Two-Proportion Equality Test. $\mathrm{N}=$ Number of subjects

Source: Research data.

Regarding oral motor impairments, in decreasing order of occurrence, the following were found: changes in tongue posture $(98 \%)$; tonus and tongue mobility (90\%); lips tonus ( $82 \%)$; lips posture $(80 \%)$; and presence of pathological oral reflexes $(56 \%)$ (Table 2).

Table 2 - Oral motor aspect for each type of cerebral palsy.

\begin{tabular}{|c|c|c|c|c|c|c|}
\hline \multirow{2}{*}{\multicolumn{2}{|c|}{ Motor Oral Appearance }} & \multicolumn{2}{|c|}{$\begin{array}{c}\text { Athetoid } \\
(\mathrm{N}=36)\end{array}$} & \multicolumn{2}{|c|}{$\begin{array}{l}\text { Spastic } \\
(\mathrm{N}=64)\end{array}$} & \multirow[t]{2}{*}{ p-value } \\
\hline & & $\mathrm{N}$ & $\%$ & $\mathrm{~N}$ & $\%$ & \\
\hline \multirow{2}{*}{$\begin{array}{c}\text { Pathological Oral } \\
\text { Reflexes }\end{array}$} & Absent & 14 & $38.9 \%$ & 30 & $46.9 \%$ & \multirow{2}{*}{0.585} \\
\hline & Present & 22 & $61.1 \%$ & 34 & $53.1 \%$ & \\
\hline \multirow{2}{*}{$\begin{array}{l}\text { Change in the } \\
\text { Lips Posture }\end{array}$} & Absent & 6 & $16.7 \%$ & 14 & $21.9 \%$ & \multirow{2}{*}{0.659} \\
\hline & Present & 30 & $83.3 \%$ & 50 & $78.1 \%$ & \\
\hline \multirow{2}{*}{$\begin{array}{l}\text { Change in the } \\
\text { Lips Tonus }\end{array}$} & Absent & 8 & $22.2 \%$ & 10 & $15.6 \%$ & \multirow{2}{*}{0.560} \\
\hline & Present & 28 & $77.8 \%$ & 54 & $84.4 \%$ & \\
\hline \multirow{2}{*}{$\begin{array}{l}\text { Change in the } \\
\text { Tongue Posture }\end{array}$} & Absent & 2 & $5.6 \%$ & 0 & $0.0 \%$ & \multirow{2}{*}{0.178} \\
\hline & Present & 34 & $94.4 \%$ & 64 & $100.0 \%$ & \\
\hline \multirow{2}{*}{$\begin{array}{l}\text { Change in the } \\
\text { Tongue Tonus }\end{array}$} & Absent & 6 & $16.7 \%$ & 4 & $6.3 \%$ & \multirow{2}{*}{0.239} \\
\hline & Present & 30 & $83.3 \%$ & 60 & $93.7 \%$ & \\
\hline \multirow{2}{*}{$\begin{array}{l}\text { Change in the } \\
\text { Tongue Mobility }\end{array}$} & Absent & 8 & $22.2 \%$ & 2 & $3.1 \%$ & \multirow{2}{*}{$0.031^{*}$} \\
\hline & Present & 28 & $77.8 \%$ & 62 & $96.9 \%$ & \\
\hline
\end{tabular}

* Statistically significant values $(\mathrm{p} \leq 0,05)$ - Two-Proportion Equality Test.

Legend: $\mathrm{N}=$ Number of subjects

Source: Research data.

There was a significant difference between the type of PC for the tongue mobility change $(p=<0.031)$, being observed more frequently in spastic cases.

The main dysphagic manifestations, in decreasing order of occurrence, were: anterior liquids escape $(70 \%)$; cough before, during or after liquid deglutition (60\%); reduction of solid food bolus formation ( $57.9 \%$ ); presence of food residues in oral cavity after solids deglutition (47.4\%); Increase in oral transit of thick pasty food $(47,1 \%)$; and presence of wet voice after liquid deglutition (30\%) (Table 3).

Table 3 - Dysphagic manifestations in each food consistency

\begin{tabular}{|c|c|c|c|c|c|c|c|c|}
\hline \multirow[t]{2}{*}{ Dysphagic manifestation } & \multicolumn{2}{|c|}{$\begin{array}{l}\text { Liquid } \\
(\mathrm{N}=80)\end{array}$} & \multicolumn{2}{|c|}{$\begin{array}{l}\text { Thickened liquid } \\
(\mathrm{N}=52)\end{array}$} & \multicolumn{2}{|c|}{$\begin{array}{c}\text { Pasty } \\
(\mathrm{N}=34)\end{array}$} & \multicolumn{2}{|c|}{$\begin{array}{c}\text { Solid } \\
(\mathrm{N}=38)\end{array}$} \\
\hline & $\mathbf{N}(\%)$ & p value & $\mathbf{N}(\%)$ & p value & $\mathbf{N}(\%)$ & p value & $\mathbf{N}(\%)$ & p value \\
\hline Anterior escape & $56(70)$ & $<0.001^{*}$ & $36(69.2)$ & $0.006^{*}$ & $20(58.8)$ & 0.303 & $26(68.4)$ & $0.023 *$ \\
\hline Increased Oral Transit & $24(30)$ & $<0.001 *$ & $22(42.3)$ & 0.267 & $16(47.1)$ & 0.732 & $12(31.6)$ & $0.023 *$ \\
\hline Reduction in the Food Bolus Formation & $24(30)$ & $<0.001 *$ & $22(42.3)$ & 0.267 & $18(52.9)$ & 0.732 & $22(57.9)$ & 0.330 \\
\hline Food residue & $8(10)$ & $<0.001^{*}$ & $10(19.2)$ & $<0.001^{*}$ & $14(41.2)$ & 0.303 & $18(47.4)$ & 0.746 \\
\hline Cough & $48(60)$ & $0.074^{\#}$ & $20(38.5)$ & $0.096^{\#}$ & $12(35.3)$ & $0.086^{\#}$ & $12(31.6)$ & $0.023 *$ \\
\hline Wet voice & $24(30)$ & $<0.001^{*}$ & $12(23.1)$ & $<0.001^{*}$ & $10(29.4)$ & $0.016^{*}$ & $10(26.3)$ & $0.004 *$ \\
\hline
\end{tabular}

* Statistically significant values $(p \leq 0,05)$ - Two-Proportion Equality Tes

Legend: $\mathrm{N}=$ Number of subjects

Source: Research data. 
Regarding the concomitant presence of global, oral and dysphagic manifestations, it was observed that the main clinical signs of tracheal aspiration, cough and wet voice were related to the change in tongue mobility and the presence of pathological oral reflexes, which, in turn, were influenced by tonic and postural alterations, in addition to the compensatory patterns (Figure 1).

Figure 1 - Influence of global and oral motor impairments on dysphagic manifestations in children with cerebral palsy

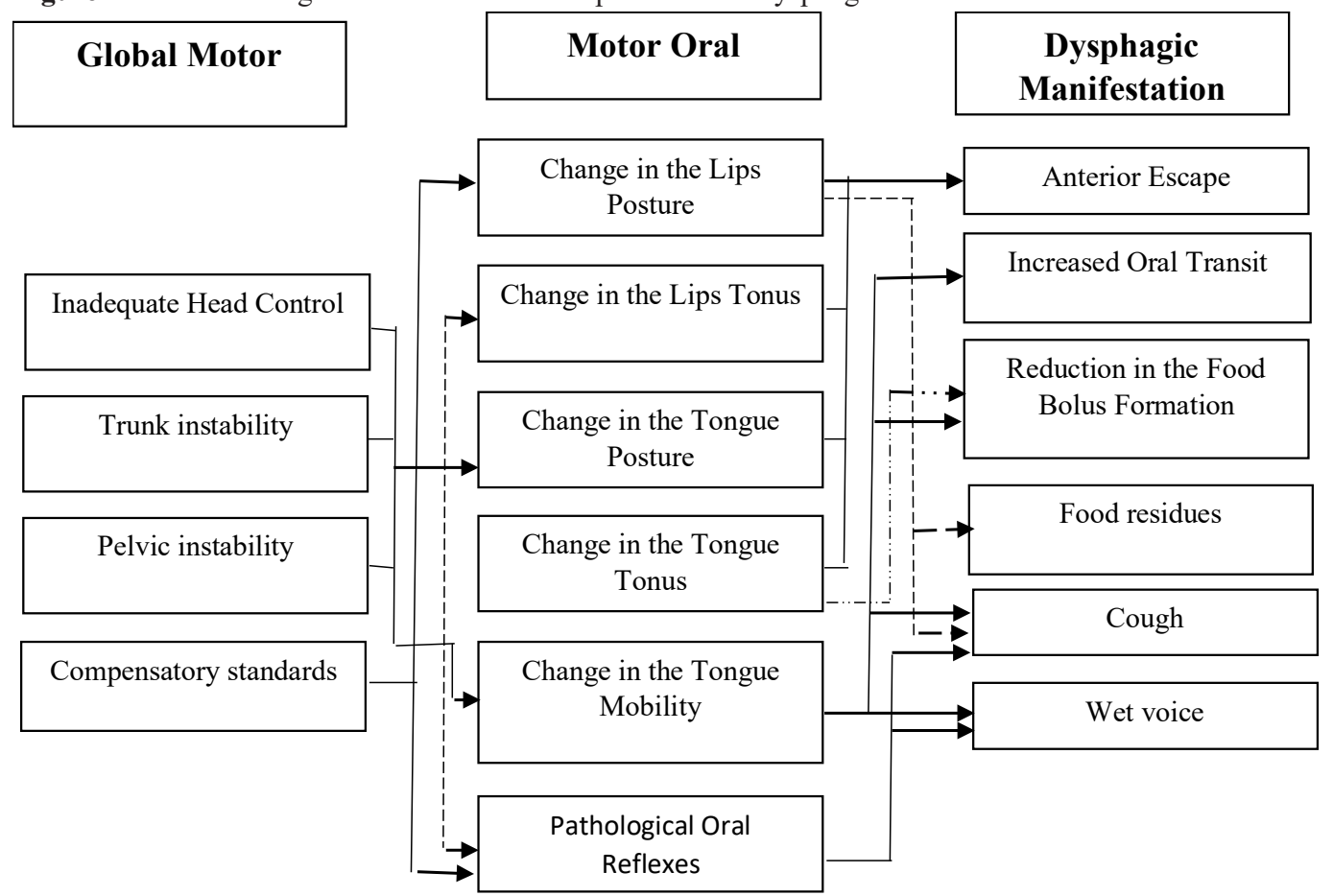

The arrows present significant correlations among the global, oral and deglutition motor alterations $(\mathrm{p}<0.05)$.

Differences in the arrows tracing were used to avoid errors in the figure reading.

Source: Research data.

The lack of balance between the extensor and flexor musculature causes fixations and proximal blockade zones, which in turn result in compensatory patterns of posture and movements. The presence of compensatory posture and movements patterns contributes to the loss of biomechanical alignment necessary for functional deglutition ${ }^{13,14}$.

The child with PC has better oral and motor ability during feeding, when he or she has pelvic stability; otherwise, the same may exacerbate his or her compensatory patterns ${ }^{15,16}$. In addition, compensatory patterns, such as head hyperextension , caused by the presence of RTCA, may lead to tongue retraction, jaw depression, and to a predisposition for tracheal food aspiration, due to the physical cranial-oral and cervical changes that make it difficult to coordinate between breathing and swallowing ${ }^{17,18}$.

There is an association between motor alterations and the presence of pathological oral reflexes, limiting the acquisition of functional oral and motor movements, which makes it difficult to capture and organize the food during the oral preparatory phase, causing the anterior escape. These changes affect the other deglutition phases, causing residues in the oral cavity and clinical signs of tracheal aspiration, such as coughing and wet voice ${ }^{19,21}$.

It is reported that tracheal aspiration occurs in approximately $25 \%$ of the cases of $\mathrm{CP}$ children, being considered as the main factors of this manifestation the change in tongue mobility, more frequent in spastic PC, the incoordination in breathing and deglutition mechanism and the lack of biomechanical alignment ${ }^{22}$.

Regarding the administration of food consistency, it was observed that the anterior escape, cough and wet voice were associated with the liquid consistency due to the incoordinated flow, since during deglutition of liquid consistency there is no need for the food bolus preparation, this justifies the rapid flow of this consistency toward the pharynx, and requires greater respiratory and muscular control to prevent food from entering the airways ${ }^{23}$.

The thickened, pasty and solid liquid consistency was related to the longer oral transit time, to the reduction of the food bolus formation and to the presence of residues after deglutition. It can be noted that, with the increase in the food bolus consistency, there was a worsening in the aspects related to difficulties in the preparation, organization, manipulation and propulsion of the bolus cake ${ }^{24}$.

There is consensus among the authors that dysphagia may also be associated with the global motor function in children with CP. In this sense, it is known that these individuals frequently use disordered movement patterns, such as scapular retraction, to improve the trunk stability, which may influence the oropharynx structures position ${ }^{8,10,25}$. 
These results agree with literature studies, indicating that impairments arising from PC may vary since changes in the oral preparatory and deglutition oral phases, even the presence of signs suggestive of laryngeal penetration and/or tracheal food aspiration ${ }^{8,18}$.

According to the data obtained in this study, it was verified that all children with CP presented global and oral motor changes influencing the deglutition dynamics. However, this study presents some limitations, among these, the size of the casuistry, the participants' age difference and the absence of objective exams such as nasofibrolaryngoscopy and deglutition videofluoroscopy.

\section{Conclusion}

Based on the above, it can be observed that the presence of compensatory patterns was more prevalent in children with longer chronological age. Whereas change in tongue mobility was more present in spastic conditions.

Therefore, the main dysphagic manifestations were: anterior saliva and food escape, increase of oral transit, decrease of the bood bolus formation, presence of food residues in the oral cavity, cough and wet voice. The presence of tonic and postural changes concomitantly with the change in tongue mobility and the presence of pathological oral reflexes were considered predominant findings for the presence of clinical manifestations suggestive of tracheal aspiration.

It is concluded that tonic and postural changes with the presence of oral impairments have resulted in deglutition disorders in children with cerebral palsy.

\section{References}

1. Gincota BE, Andersen GL, Torstein V, Jahnsen R. Paralisia cerebral na Moldávia: subtipos, gravidade e deficiências associadas. BMC2018;18(1):332. doi: 10.1186/ s12887-018-1305-6.

2. Velde A, Morgan C, Novak I, Tantsis E, Badawi N, Rosenbaum P, et al. Diagnóstico precoce e classificação da paralisia cerebral : uma perspectiva histórica e barreiras ao diagnóstico precoce. J Clin Med 2019;8(10). doi: 10.3390/ jcm8101599.

3. Pierce SR, Paremski AC, Skorup J, Stergiou N, Senderling B, Prosser LA. Medidas lineares e não lineares do controle postural em uma criança com paralisia cerebral : breve relatório. Pediatr Phys Ther 2020;32(1):80-3. doi: https:// insights.ovid.com/crossref?an=00001577-202001000-00017

4. Rosenbaum P, Rosenbloom L. Cerebral palsy: from diagnosis to adult life. Press Develop Med Child Neurol 2012;55(3):292.

5. Smithers-Sheedy H, Badawi N, Blair E, Cans C, Himmelmann $\mathrm{K}$, Krägeloh-Mann I, et al. What constitutes cerebral palsy in the twenty-first century? Dev Med Child Neurol 2014;56 (4):323-8. doi: https://doi.org/10.1111/dmcn.12262

6. ZP, Caird MS, Whitney DG. Epidemiologia da osteoporose entre adultos com paralisia cerebral: resultados de dados de reivindicações administrativas privadas e públicas. JBMR Plus 2019;3(11): e10231. doi: 10.1002 / jbm4.10231.

7. Benfer KA, Weir KA, Bell KL, Ware RS, Davies PSW, Boyd RN. Disfagia orofaríngea e paralisi cerebral Pediatria
2017;140(6). doi: 10.1542/peds.2017-0731.

8. Marshall J, Parkes J, Hill N, Platt MJ, Donnelly C. Alimentação infantil anatomia e fisiologia. Parteira Prática 2012;15(9):38-41.

9. Parkes J, Hill J, Platt M, Donnelly C. Oromotor dysfunction and communication impairments in children with cerebral palsy: a register study. Develop Med Child Neurol 2010;52(12):1113-9. doi: https://doi.org/10.1111/j.14698749.2010.03765.x

10. Clancy K, Hustad K. Longitudinal changes in feeding among children with cerebral palsy between the ages of 4 and 7 years. Dev Neurorehabil 2011;14(4):191-8. doi: https://doi.or $\mathrm{g} / 10.3109 / 17518423.2011 .568467$

11. Erasmus C, Hulst K, Rotteveel JJ, Willemsen MA, Jongerius PH. Clinical practice: swallowing problems in cerebral palsy. Euro J Pediatr 2012;171(3):409-14. doi: https://doi. org/10.1007/s00431-011-1570-y

12. Veugelers R, Benninga MA, Calis EA, Willemsen SP, Evenhuis $\mathrm{H}$, Tibboel D, et al. Prevalence and clinical presentation of constipation in children with severe generalized cerebral palsy. Dev Med Child Neurol 2010;52(9):216-21. doi: https://doi.org/10.1111/j.1469-8749.2010.03701.x

13. Salghetti A, Martinuzzi A. Dysphagia in cerebral palsy. Eastern J Med 2012;17(4):188-93.

14. Duffy KL. Disfagia em crianças. Curr Probl Pediatr Adolesc Health Care 2018;48(3):71-3. doi: 10.1016 / j.cppeds.2018.01.003. SSEP Saavedra S, Woollacott M, Donkelaar P. Head stability during quiet sitting in children with cerebral palsy: effect of vision and trunk support. Exp Brain Res 2010;201(1):13-23. doi: https://doi.org/10.1007/ s00221-009-2001-4

15. Woisard V, Custo M, Colineaux H, Página B. Como um dispositivo dobrável transportável personalizado para assentos afeta a disfagia. Eur Arch Otorhinolaryngol 2019. doi: 10.1007 / s00405-019-05657-5.

16. Menezes EC, Santos FAH, Alves FL. Disfagia na paralisia cerebral: uma revisão sistemática. Rev CEFAC 2017;19(4):565-74. doi: http://dx.doi.org/10.1590/1982021620171944317

17. Nemkova SA. Fala distúrbios em crianças com paralisia cerebral: diagnóstico e correção. Zh Nevrol Psikhiatr Im SS Korsakova 2019;119(5):112-9. doi: 10.17116/ jnevro2019119051112.

18. Sino KL, Benfer KA, Ware RS, Patrao TA, Garvey JJ, Arvedson JC, et al. Desenvolvimento e validação de uma ferramenta de triagem para dificuldades de alimentação/ deglutição e desnutrição em crianças com paralisia cerebral. Dev Med Child Neurol 2019;61(10):1175-81. doi: 10.1111 / dmcn. 14220 .

19. Silvério CC, Gonçalves, MIR. Nível de comprometimento motor e deglutição em pacientes com paralisia cerebral. Rev Bras Neurol 2019;55(1):5-11.

20. Lawlor CM, Choi S. Diagnóstico e manejo da disfagia pediátrica: uma revisão. JAMA Otolaryngol Head Neck Surg 2019. doi: 10.1001 / jamaoto.2019.3622.

21. Lucchi C, Flório CPF, Silvério CC, Reis TM. Disfagia orofaríngea na paralisia cerebral. Rev Soc Bras Fonoaudiol 2009;14(2):172-6.

22. Nip ISB, Wilson EM, Kearney L. Características espaciais dos movimentos mandibulares durante a mastigação em crianças com paralisia cerebral: um estudo piloto. Disfagia 
2018;33(1):33-40. doi: 10.1007/s00455-017-9830-2.

23. Benfer KA, Weir KA, Bell KL, Ware RS, Davies PSQ, Boyd $\mathrm{RN}$. Oropharyngeal dysphagia and gross motor skills in children with cerebral palsy. Pediatrics 2013;131(5):1553-62. doi: http://dx.doi.org/10.1542/peds.2012-3093 